\title{
Strategic Sales Conversations As A Foundation For Effective Partnership Selling
}

C. David Shepherd, Georgia Southern University, USA

Morgan P. Miles, Georgia Southern University, USA

Linda S. Munilla, Georgia Southern University, USA

\begin{abstract}
This paper presents a new sales organization tool, strategic sales conversations, that can be used to enhance relationships with customers. Strategic sales conversations are an adaptation of strategic conversations in an inter-and intra- organizational context in which the selling firm is attempting to utilize open and honest communication to better understand the long-term needs of the buying organization. A process model of strategic sales conversations is developed and its implications are discussed.
\end{abstract}

Keywords: Partnership selling, strategic conversations, value creation

\section{INTRODUCTION}

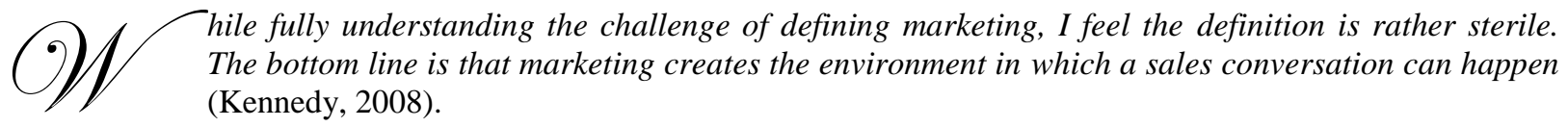

The American Marketing Association (AMA) recently revised its definition of marketing to better reflect current practices and emerging philosophies in the discipline: "Marketing is the activity, set of institutions, and processes for creating, communicating, delivering, and exchanging offerings that have value for customers, clients, partners, and society at large" (Keefe 2008). The new version reinforces the 2004 AMA definition that focused on value and supported what may be the raison d'être for the business discipline of marketing - effectively leveraging processes, activities, and communications with the customer to create superior value. Value creation is also now perceived as a critical practice in selling and sales management, and proactive sales organizations are adopting a "firm's selling orientation" (FSO) based on strategically building and maintaining value by creating long-term relationships (Ingram et al. 2006; Jolson 1997; Frankwick, Porter, and Crosby 2001; Guenzi 2002 and 2003; Gonzalez, Hoffman, and Ingram 2005).

In the previous era of selling, transactional selling focused on the salesperson and the selling firm, utilizing a one-way model of communication from salesperson to customer. The current era of selling, relationship selling, is customer-centered and uses a two-way collaborative model of communication between customer and salesperson (Ingram et al. 2006:24). Effective sales organizations become focused on building and maintaining an on-going and mutually beneficial, value creating relationship between the selling and buying organizations (Gonzalez, et al. 2005). Tremendous competitive pressures, cost constraints, and the economic realization that the longer an organization keeps a "good, high value" customer the more profitable the organization will become, have reinforced the need for extended relationship selling (Reichheld \& Sasser 1990).

As the selling discipline has moved from a transactional to a relationship focus, a partnership model of the selling process has also evolved. For example, the traditional transactional model of the selling process suggested that the sale ended when the salesperson "closed the sale" (Shinn 1982). However, during the 1980's, more attention was given to the relationship outcomes generated by the sales process (see, for example, Dwyer, Schurr, \& Oh 1987; Miles, Arnold, \& Nash 1990). Some of the more traditional scholars augmented the traditional transaction process model by simply adding a relationship building stage that should occur after the sale has been made. 
However, this simplistic approach ignores the value creating capabilities of effective and honest collaborative communications between the buyer and seller that result in enhanced satisfaction for both the buyer and seller.

The traditional approach to transactional selling suggested that the salesperson's role was not to understand the needs of the customer through collaborative interactive communications but to (1) discover prospects in the market, (2) create a commitment with the prospect through contact and making an appointment, (3) make a sales presentation to convert the prospect, (4) handle objections, and (5) always close the sale, regardless of whether the sale was in the customer's, or even the seller's, best long term interest (for examples, see Shinn 1982; Futrell 1984). Weitz and Bradford (1999) found that "partnering-oriented salespeople are value creators" (243) and that managing conflict in the buyer-seller relationship will become a major part of partnership selling.

Today's partnership-oriented salesperson knows that before a product or service is presented, s/he must uncover the customer's latent and manifest needs through a deep understanding of customer problems. As one current sales text points out, "(u)sing a consultative, problem-solving approach, the professional salesperson can efficiently uncover the prospect's perceived problems and needs by skillful questioning and careful listening" (Anderson, Dubinsky, and Mehta 2007:174). Since the late 1980's, skillful questioning and careful listening, in what Anderson, et al. (2007) called the "Pivotal Exchange," have emerged as key tools of the relationship-oriented salesperson. In fact, arguably, the most widely used sales methodology to be developed over the past two decades, SPIN Selling (Rackham 1988), is essentially a framework or formula for asking effective questions.

\section{VALUE CREATION AND PARTNERSHIP SELLING}

Value has emerged as the core of the most recent definition of marketing but it is not a new term in the sales lexicon. In fact, the concept of value has long been intertwined with the selling process. In 1952 a sales executive with Philip Morris commented that his company's sales force was trained to deliver extra value to their customers (White 1952). In recent years, practitioners and academics alike have come to believe that success in the sales position required the ability to communicate value to the customer (for example, see Rackman and DeVincentis1999). At the same time, others have suggested that salespeople must also learn to create value for the customer (for example, see Ingram 1995) through a superior understanding of the customer's needs and the ability of the sales organization to most effectively satisfy these needs with a targeted market offering.

This movement from communicating value to using collaborative communication to create value parallels, in many respects, the shift from a transactional perspective to a relationship-oriented perspective seen in professional selling. In the early days of selling, and until the mid 1980's, the primary role of the salesperson was to persuade customers to buy products through the delivery of a well-crafted sales "pitch." In the mid to late 1980's, the sales process became more of an interactive process. Using approaches such as SPIN selling, salespeople were trained in the art of asking questions in order to discover latent buyer needs. In the SPIN selling approach, salespeople are trained to gather information from the prospect by asking a series of situation, problem, implication, and need payoff questions that will illustrate that one of the salesperson's products is the best solution (Rackham 1988). In other words, essentially SPIN selling provides a framework for questioning or interrogating prospects that is designed to result in a sale. Table 1 provides an example of the SPIN Selling format. However, SPIN selling never encouraged honest, open inter- or intra-organizational communication, but rather generated highly structured and mediated questions and responses directed by the salesperson with the objective of closing the sale efficiently. Once customer needs were uncovered through a series of questions, the seller would attempt to create value by matching the sales organization's product offerings with the perceived customer needs. Recently, it has been suggested that the sales profession is transitioning once again into a new era, partnership selling, where inter- and intra-organizational communication is more open and unfiltered (Weitz, Castleberry, and Tanner 2004).

Partnership selling is simply an extension of relationship selling in which the salesperson focus has moved to a deeper, long-term understanding of the customer's manifest and latent needs coupled with the knowledge of how both parties might benefit from an enhanced relationship. According to Weitz, et al. (2004), open communication is a hallmark of the partnering sales/buyer relationship. The SPIN Selling method has been an extremely effective approach used to generate effective questioning and interrogation. However, in partnership selling, the seller needs to be able to open an ongoing conversation designed to create value for both parties, not a simple question and answer session designed to sell the product to the prospect. The move from a skillful 
questioning approach to the creation of an on-going conversation with a prospect may be as difficult a transition as was the change from simply making presentations to the asking of questions to find the prospect's needs prior to presenting. Just as SPIN Selling helped salespeople learn to ask skillful questions, a method is now needed to help salespeople learn to move beyond questioning in order to build effective, mutually value-creating communication.

Table 1

An illustration of the SPIN Selling Framework

Step 1. Situation Question:

Salesperson: What has been your company's growth rate over the past year?

Prospect: We have grown at an amazing rate. Sales are up over $60 \%$ !

Step 2. Problem Question:

Salesperson: Have any problems emerged as a result of that rapid growth rate?

Prospect: Well, there have been some growing pains. For example, we have been so busy that, at times, we have had a hard time making on-time deliveries to our customers.

Step 3. Implication Question:

Salesperson: What tends to happen when you miss a delivery promise to a customer?

Prospect: Well, it has resulted in reduced customer satisfaction and some customers defecting to competition.

\section{Step 4. Need Payoff Question:}

Salesperson: If I can show you a way that we can reduce or eliminate late deliveries without having to increase staff or overtime, would you be interested?

Prospect: Of course we would be!

The purpose of this manuscript is to present such a tool, the strategic conversation approach. The strategic conversation approach has emerged as a very effective method of developing open channels of honest, unfiltered communication within organizations between top managers and boundary-spanning marketing, technology, and sales employees (Miles, Munilla, and Darroch 2006). In addition, strategic conversations can be used effectively between organizations to better understand each organization's needs and priorities (Miles, et al. 2006). In the discussion that follows, the authors will present the strategic conversation approach and discuss how it can be applied to the selling process as it moves into the partnering era.

\section{STRATEGIC CONVERSATIONS IN A PARTNERSHIP SELLING CONTEXT}

Van der Heijden, Bradfield, Caims, and Wright (2002) refer to strategic conversations as a strategy of adaptive organizational learning that uses scenario planning, both negative and positive, to examine potential situations and their various consequences. Miles, et al. (2006) suggest that "(s)trategic conversations are multidirectional, multi-dimensional communication mechanisms for better shaping and integrating the strategic intent of top management with both the firm's capabilities and the competitive realities the organization encounters" (196). Covin and Miles (2007) propose that strategic conversations enhance a firm's capabilities to leverage strategic initiatives by creating open, unfiltered communication channels between top management and the firm's boundary spanning employees (BSEs) that interact with the firm's customers, competitors, and technologies. The quality and context of this type of frank discussion between strategy makers and strategy implementation tends to result in enhanced strategy and implementation (Liedtka and Rosenblum 1996). Table 2 illustrates the differences in 
lifespan of the relationship, flow of information, nature and goals of communication, actors involved, and the relative costs and efforts of the sales process between a transactions and partnership FSO (firm's selling orientation). Figure 1 illustrates the organizational actors and flow of communications in a typical partnership selling relationship.

Table 2

Firm selling orientations and the role of strategic conversations

\begin{tabular}{|l|l|l|}
\hline Sales Orientation Era & Transactions Firm Selling Orientation & \multicolumn{1}{|c|}{ Partnership Firm Selling Orientation } \\
\hline $\begin{array}{l}\text { Life of sales } \\
\text { relationship }\end{array}$ & Short-term & Long-term \\
\hline Flow of information & $\begin{array}{l}\text { Uni-directional from the Salesperson to } \\
\text { the Purchaser }\end{array}$ & $\begin{array}{l}\text { Interactive and on-going, } \\
\text { that generate intra- and inter- firm strategic } \\
\text { conversations on value creation through leveraging } \\
\text { this relationship }\end{array}$ \\
\hline $\begin{array}{l}\text { Nature of } \\
\text { communication }\end{array}$ & Salesperson "pitches" the good or service & $\begin{array}{l}\text { Salespersons, customers and top management have } \\
\text { meaningful, open, and unfiltered conversations over } \\
\text { an extended period of time that create higher value } \\
\text { relationships for both that may impact the } \\
\text { organization's concept of strategy }\end{array}$ \\
\hline $\begin{array}{l}\text { Goal of } \\
\text { communication }\end{array}$ & $\begin{array}{l}\text { Deep learning with the ultimate goal of creating a } \\
\text { mutually beneficial long-term relationship that } \\
\text { generates an on-going stream of value to both the sales } \\
\text { and purchasing organizations }\end{array}$ \\
\hline $\begin{array}{l}\text { Principal actors in the } \\
\text { sales relationship }\end{array}$ & $\begin{array}{l}\text { The salesperson and the customer/client } \\
\text { (Individuals })\end{array}$ & $\begin{array}{l}\text { The sales organization and the purchasing } \\
\text { organizations }(\text { Organizations })\end{array}$ \\
\hline Sales costs, efforts & $\begin{array}{l}\text { Relatively lower costs and efforts as each } \\
\text { sale is viewed as a one-time transaction }\end{array}$ & $\begin{array}{l}\text { Relatively high costs and efforts - However, due to } \\
\text { the long term nature may result in lower selling efforts } \\
\text { and costs over time }\end{array}$ \\
\hline
\end{tabular}

\section{Figure 1}

\section{Strategic Conversations and Partnership Selling}

\section{Sales Organization}

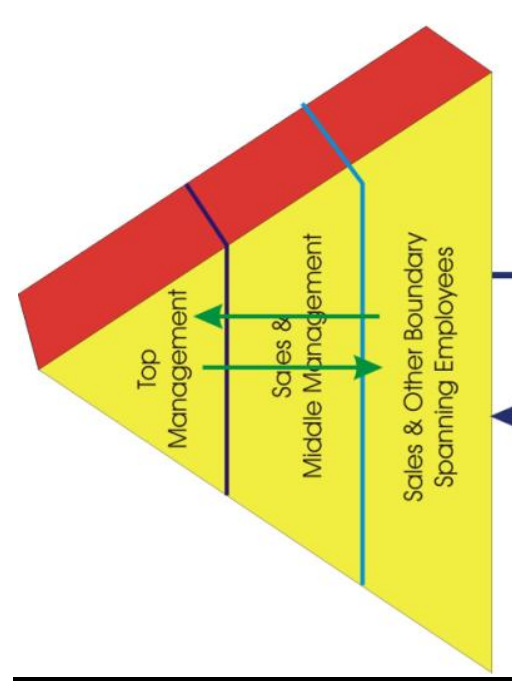

\section{Purchasing Organization}

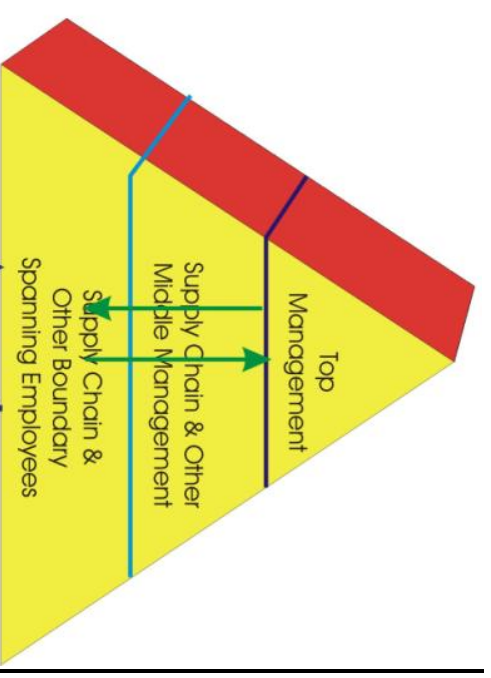


In a partnership sales context, strategic conversations can be conceptualized as multi-directional, multilevel inter- and intra- organizational communications that help integrate the capabilities of the selling organization with both the latent and manifest needs of the purchasing organization. Strategic conversations can become the mechanism used to create and build a long-term partnership between the purchasing and selling organization through the sharing of mutually beneficial honest, unfiltered strategic information and the creation of inter- and intra-organizational strategy. The usefulness of strategic conversations in partnership selling becomes apparent in situations that require enhanced communications between the buying and selling organizations due to a significant commitment of resources by the selling organization. Strategic sales conversations may be most useful in strategic partnerships such as single sourcing, just-in-time (JIT) inventory systems, high-tech based radical and disruptive innovations, and/or the creation of new business value propositions. Strategic conversations through inter- and intra-organizational communication flows can help alter and shape both firms' concept of strategy, ultimately resulting in a stronger competitive position for both.

Partnership selling creates a link between organizations, not simply people, and by creating a more structured, long-term relationship, partnership selling spreads the typically high costs that accrue in partnership selling over many individual sales. A firm considering adopting a partnership FSO should understand that a partnership FSO results in much higher fixed costs allocated to selling than if the firm simply follows the traditional transactions FSO. However, the ability of partnership FSOs to leverage strategic sales conversations to create superior value propositions, build long-term structural and strategic linkages, and enhance the efficiency and effectiveness of the sales process may often more than compensate for the additional selling costs.

\section{A PROCESS MODEL OF STRATEGIC SALES CONVERSATION IMPLEMENTATION}

Strategic sales conversations require open, honest, and unfiltered information flows between the BSEs of the buying and selling organizations and the ability of open, honest, and unfiltered conversations between the boundary spanning employees (BSEs) and each organization's executives. As illustrated in Figure 1, these interand intra- strategic sales conversations allow both parties to engage in a collaborative value creation process that, in many ways, reflects marketing theory's transition towards co-production and a service dominant logic of marketing (see Vargo and Lusch 2004).

The strategic sales conversation process consists of seven steps: (1) both the selling and buying organization have an understanding of their unique concept of strategy through honest and unfiltered communication between top management and BSEs (the sales team and the buying center respectively); (2) these concepts of organizational and business level strategy are fully understood by each organization's BSEs; (3) BSEs from the selling and buying organization meet to discuss long-term strategies, capabilities, and inter- and intra- organizational needs; (4) common interests and matches between the needs of one organization and the capabilities of the other organization are specified; (5) solutions to these needs are offered; (6) the relationships of these inter- and intraorganizational needs/capabilities are discussed frankly with each firm's top management; and, finally, (7) these short- and long-term sales relationships impact both the selling and buying firm's concept of strategy. The seven steps of strategic sales conversations greatly enhance inter- and intra- organizational links and move the selling firm to an effective partnership FSO.

Organizations interested in adopting strategic sales conversations and a partnership selling FSO may find it useful to use a neutral, off-site location as a retreat and invite key employees from both the buying and selling organization at the boundary spanning and executive levels for a day of strategy "brainstorming" in which the longterm needs, capabilities, and objectives of each organization are considered. The goal of this type of session is to create a mutually beneficial exchange partnership with long-term strategic implications. However, for this process to be most effective, the executives of each organization must commit to collaborate and not engage in zero sum games between or within the organizations.

\section{CONCLUSIONS}

Strategic sales conversations are one mechanism that may help create and enhance the partnership selling approach. For strategic sales conversations to be most effective, the process must be supported at the executive 
level of each organization by providing the resources to engage in strategic conversations as well as the willingness to share information with BSEs. The process of strategic sales conversations begins and ends with the firm's concept of strategy. In between, each firm must honestly and openly assess their needs and capabilities and attempt to partner with the other to gain competitive advantage.

While strategic sales conversations are intended to create long-term partnerships, obliviously, an organization's concept of strategy can be altered by many influences and, therefore, must remain flexible and adaptive. However, in an economic, technological, and regulatory environment with increasing complexity and turbulence, for firms to realize their strategic intent, they often need the capabilities of other partners. Strategic sales conversations offer one mechanism for inter- and intra- alignment through honest, open, and unfiltered conversations between ground level employees and top management.

\section{AUTHOR INFORMATION}

C. David Shepherd is professor of marketing and director of the Center for Excellence in Sales \& Sales Management at Georgia Southern University. Dave earned his PhD from the University of Tennessee and conducts research on sales and sales management.

Morgan P. Miles is professor of marketing at Georgia Southern University, and has been a visiting professor at the University of Stockholm, the University of Otago, and Massey University. In addition, he was a senior research associate at Cambridge University. He earned his DBA from Mississippi State University in 1989. Morgan's research interests are in the interface of marketing and entrepreneurship.

Linda S. Munilla is professor of marketing at Georgia Southern University. She earned her EdD from Virginia Tech. Her research interests include marketing and ecological standards/ethics.

\section{REFERENCES}

1. Anderson, R.E., Dubinsky, A.J., \& Mehta, R. (2007). Personal Selling: Building Customer Relationships and Partnerships. Boston, MA: Houghton Mifflin Company.

2. Covin, J.G. \& Miles, M.P. (2007). "The Strategic Use of Corporate Venturing,” Entrepreneurship Theory and Practice, 31(2): 183-207.

3. Dwyer, F.R., Schurr, P.H.,\& Oh, S. (1987). "Developing Buyer-Seller Relationships,” Journal of Marketing, 51(2), 11-28.

4. Frankwick, G.L., Porter, S.S., \& Crosby, L.A. (2001). "Dynamics of Relationship Selling: A Longitudinal Study of Changes in Salesperson-customer Relationship Status," Journal of Personal Selling \& Sales Management,(21(2), 135-136.

5. $\quad$ Futrell, C. (1984). Fundamentals of Selling. Homewood, IL: R.D. Irwin.

6. Gonzalez, G.B., Hoffman, K.D., \& Ingram, T.N. (2005). "The Sales Recoverty Audit: A Tool for Enhancing Buyer-Seller Relationships," Proceedings of the National Sales Conference in Sales Management, CD.

7. Guenzi, P. (2002), "Sales Force Activities and Customer Trust," Journal of Marketing Management, 18(7/8): 749-778.

8. Guenzi, P. (2003), “Antecedents and consequences of a firm's selling orientation,” European Journal of Marketing, 37 (5/6): 706-727.

9. Ingram, T.N. (1995). "Relationship Selling: Moving from Rhetoric to Reality," Mid-American Journal of Business, 11 (Spring), 5-13.

10. Ingram, T.N., LaForge, R.W., Avila, R.A., Schwepker, Jr., C.H., \& Williams, M.R. (2006). Sales Management: Analysis and Decision Making. Mason, $\mathrm{OH}$ : Thomson South-Western.

11. Jolson, M.A. (1997). "Broadening the Scope of Relationship Marketing," Journal of Personal Selling \& Sales Management, 17(4), 75-88.

12. Keefe, L.M. (2008). “Marketing Defined,” Marketing News, January 15, 2008. 
13. Kennedy, Kurt (2008, May). AMA Blog. http://appserver.marketingpower.com/blog/amablog/2008/01/the americanmarketing_associa.html\#comme $\underline{\text { nts }}$

14. Liedtka, J.M. \& Rosenblum, J.W. (1996). "Shaping conversations: Making strategy, managing change," California Management Review, 39(1): 141-157.

15. Miles, M.P., Arnold, D., \& Nash, H. (1990). “Adaptive communication: The adaptation of the seller's interpersonal style to the stage of the dyad's relationship and the buyer's communication style," Journal of Personal Selling and Sales Management, 10 (1): 21-27.

16. Miles, M.P., Munilla, L., \& Darroch, J. (2006). "The role of strategic conversations with stakeholders in the formation of Corporate Social Responsibility Strategy," Journal of Business Ethics, 69: 195-205.

17. Rackham, N. (1988), SPIN Selling, New York, NY: McGraw-Hill.

18. Rackham, N., \& DeVincentis, J. (1999). Rethinking the Sales Force: Redefining Selling to Create and Capture Customer Value. New York, NY: McGraw-Hill.

19. Reichheld, F.F., \& Sasser, Jr., W.E. (1990). “Zero Defections: Quality Comes to Services,” Harvard Business Review, 68(5), 105-111.

20. Shinn, G. (1982). An Introduction to Professional Selling. New York, NY: McGraw Hill.

21. Van der Heijden, K., Bradfield, R., Burt, G., Caims, G. \& Wright, G. (2002). The Sixth Sense: Accelerating Organization Learning with Scenarios. New York, NY: John Wiley \& Sons LTD.

22. Vargo, S.L. \& Lusch, R.F. (2004). "Evolving to a new dominant logic for marketing." Journal of Marketing, 68 (January):1-17.

23. Weitz, B.A., \& Bradford, K.D. (1999). "Personal Selling and Sales Management: A Relationship Marketing Perspective,” Journal of the Academy of Marketing Science, 27(2), 241+.

24. Weitz, B.A., Castleberry, S.B., \& Tanner, J.F. (2004). Selling: Building Partnership, Boston: McGraw Hill.

25. White, Harry R. (1952), America's Twelve Master Salesmen. New York, NY: B. C. Forbes \& Sons Publishing Co, Inc. 
NOTES 